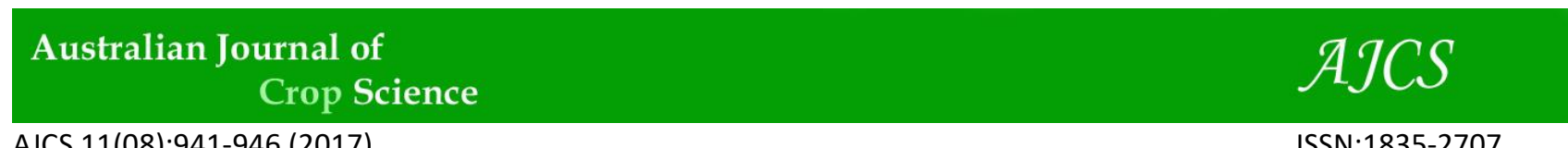

AJCS 11(08):941-946 (2017)

ISSN:1835-2707

doi: 10.21475/ajcs.17.11.08.pne351

\title{
Wheat phenology and yield under drought: A review
}

\section{Marcos Vinicius Mansano Sarto*1, Jaqueline Rocha Wobeto Sarto ${ }^{1}$, Leandro Rampim ${ }^{2}$, Jean Sérgio Rosset $^{3}$, Doglas Bassegio ${ }^{1}$, Poliana Ferreira da Costa ${ }^{4}$, Adriano Mitio Inagaki ${ }^{4}$}

\author{
${ }^{1}$ São Paulo State University (UNESP), Department of Crop Science, Botucatu, São Paulo, Brazil \\ ${ }^{2}$ State University of Midwest (UNICENTRO), Guarapuava, Paraná, Brazil \\ ${ }^{3}$ State University of Mato Grosso do Sul - UEMS \\ ${ }^{4}$ West Paraná State University (UNIOESTE), Marechal C. Rondon, Brazil
}

*Corresponding author: marcos.sarto28@gmail.com

\begin{abstract}
The purpose of this review was to characterize the wheat crop phenology under drought conditions, at different stages of crop growth. Effects of drought on wheat plants are variable, and depend on the phenological stage of the plant as well as the duration, intensity and frequency of the drought. The crop evapotranspiration increases over the course of the phenological cycle, reaching a maximum in the growth stage (from the beginning of heading until the end of flowering), which is the most sensitive stage of the crop to drought. At ripening, the evapotranspiration decreases to save and allocate the energy to grain yield. The drought affects the plant density in the initial phase, tiller number per plant in the tillering phase, and plant height in the stretching phase, most severely. At the flowering stage, the processes related to fertilization and fixation of grain are most severely affected, i.e., the number of viable seeds per area decreases. In the grain formation stage, the ability of the source (leaf) to use and translocate the assimilates to the grain is most severely affected, thus affecting the grain weight.
\end{abstract}

Keywords: Triticum aestivum L., water stress, growth stages.

Introduction

Wheat (Triticum aestivum L.) is an annual plant; wheat grains are consumed in the form of bread, pasta, cakes, and biscuits. When wheat does not reach the required quality for human consumption, the grains are destined for animal feed (Embrapa Trigo, 2015). Wheat was one of the first plants to be cultivated by man, between 7000 and 9000 B.C., as humans began to expand their population throughout the world, and for 8000 years it has been a staple food of the major civilizations of Europe, Asia, and Africa (Vesohoski et al., 2011). Wheat has been cultivated in Southeast Asia, its center of origin, for more than 10,000 years. It belongs to the family Poaceae, tribe Triticeae (Hordeae), sub-tribe Triticinae, and genus Triticum. The sub-tribe comprises 15 species, gathered in three groups named according to the number of chromosomes; the diploid species have 14 chromosomes $(\mathrm{n}=7)$, tetraploid species contain 28 chromosomes, and the hexaploids have 42 chromosomes (Sleper and Poehlman, 2006). The Triticum genus contains approximately 30 species, half of which are grown commercially, and the other half grows in a wild form. Over $90 \%$ of the wheat species grown worldwide corresponds to Triticum aestivum vulgaris and Triticum turgidum durum (Abitrigo, 2015). Triticum aestivum L., known as common wheat, is the species of greatest commercial interest, given its suitability for baking. Grains of the species $T$. durum lack the gliadin and glutenin proteins, and are therefore not suitable for baking. This species, however, outweighs the other species in the qualities needed to manufacture noodles (Moreira and Souza, 1999). Wheat is one of the most ancient and noble cereals to be used as food; the quality and quantity of protein are an important component in the human diet. It is also used in the preparation of drugs and glue, as well as in animal feed, as fodder, grain, or feed composition (Embrapa Trigo, 2015). The world wheat production in the 2014/2015 harvest was 716.11 million tons, and the largest producing areas were China, India, the European Union, Russia, and the United States. Brazilian wheat production in 2014/2015 reached 5.971 million tons, whereas the annual consumption in the country has remained around 10 million tons (USDA, 2015), and the states of Paraná, Rio Grande do Sul, and Santa Catarina accounted for $90 \%$ of the total wheat production in Brazil (Embrapa Trigo, 2015). Brazilian wheat production has not been sufficient to meet the domestic demand. This situation has been aggravated by the high amount of grain that is destroyed or reduced in quality by pests, germination of the ears, and reduced dry matter due to delayed harvests (Gutkoski et al., 2008). The lack of production incentives, small acreage, and low productivity ceilings also contribute to the annual deficit in Brazilian wheat production. However, the wheat crop in Brazil has improved, every day, on the most important fronts of producers and exporting countries, based on productivity gains, profitability, and improving industrial quality (Tibola et al., 2008; Boschini, 2010).

Interest in maximizing the yield of wheat has stimulated the use of intensive management in this culture. This management includes the adoption of certain practices such as sowing, spacing, density-appropriate seeding, increasing soil fertility levels, controlling disease and insects, and plant lodging (Rodrigues and Teixeira 2003).

\section{The phenological stages of wheat}

Knowledge of wheat plant development is extremely important to understand the possible limitations caused by the environment, especially the water deficit. According to 
Doorenbos and Kassam (1979), the water requirements of wheat crops can range from 450 to $650 \mathrm{~mm}$, over its entire cycle ranging from 95 to 125 days. When plants suffer drought stress, they close their stomata to prevent dehydration. The absorption and water loss in the guard cells changes their turgor and modulates the opening and closing of the stomata, through hydropassive (without energy expenditure) and hydroactive (with energy expenditure) movements. With the closing of the stomata, there is a drastic reduction in transpiration rates, because most of the plant's transpiration is stomatal, with the remainder performed by the cuticle (Taiz and Zeiger, 2004). When undergoing drought stress, plants increase the production of abscisic acid by as much as 50-fold in leaves, which decreases leaf area due to lower-turgor-pressure cells, stomatal closure, the induction of senescence and ethylene production (Taiz and Zeiger, 2013). The water deficit initiates a complex pathway response, starting with the perception of stress triggering a sequence of metabolic pathways. This can result in various levels of physiological responses, both metabolic and developmental. A change in the osmotic potential, relative to the plasma membrane, can be a major cause of response to water stress at the molecular level (Bray, 1993). In water-stress conditions, various physiological and morphological processes, such as the decrease of turgor pressure in cells, leaf expansion, leaf abscission, the deepening of roots in the soil, stomatal conductance, and photosynthesis are changed (Bajaj et al., 1999; Taiz and Zeiger, 2004; Zhu et al., 2005). Water stress also affects many important biochemical processes such as osmotic adjustment, antioxidant enzyme defense system, abscisic acid production, and lipid peroxidation. There are, however, morphological, physiological, and biochemical processes able to confer drought resistance (Mitra, 2001; Sarto et al., 2016). The increase in $\mathrm{Si}$ in the plant can increase the efficiency of water use by some grasses (Sarto et al., 2012, Sarto et al., 2015, Sarto et al., 2016). Most cultivated plants are sensitive to water stress, particularly during the flowering and seed development stages; reduction in productivity can be seen as a result of this condition (Slatyer, 1969). Slatyer (1969) and Rodrigues et al. (1998) highlighted three critical periods wherein the occurrence of drought most affects the wheat crop: floral initiation and inflorescence development, anthesis and fertilization, and grain formation. Moreover, Intalap and Day (1970) reported shoot elongation of the plant as a critical period. According to Fischer (1973), the greatest reductions in the yield of wheat grains occur when there is water deficiency in the plant development period, spanning 15 days before and 5 days after heading. The photosynthetic rate of a leaf (expressed by unit leaf area) is rarely as responsive to moderate stress as the leaf expansion, because photosynthesis is much less sensitive to turgor. With the closing of the stomata during the early stages of water stress, water-use efficiency can increase (i.e., more $\mathrm{CO}_{2}$ can be absorbed by water transpired per unit leaf area). Under severe stress, however, the dehydration in mesophyll cells inhibits photosynthesis as well as mesophyll metabolism, and wateruse efficiency decreases as a result (Taiz and Zeiger, 2004). On plant growth, Kramer (1983) states that water stress usually causes multiple effects, such as reducing the assimilative capacity by decreasing photosynthesis, through stomatal closure and the loss of leaves and thus the leaf area. This results in decreased carbon dioxide supply, which reduces the translocation of carbohydrates and plant-growth regulators, and causes disturbances in nitrogen metabolism. These effects add to the reduced swelling, reduced growth and decreased crop productivity. Damage caused by water stress varies according to the duration, intensity, frequency, and time of occurrence in the culture. The frequency and intensity of water deficit are the main limiting factors in global agricultural production (Santos and Carlesso, 1998; Damatta, 2007). Water stress is a situation common to many cultures, influencing almost every aspect related to plant development (Damatta, 2007). Grant (1992), however, states that the development of the adaptation mechanisms of plants to drought stress is influenced by the level of $\mathrm{CO}_{2}$, solar radiation, temperature, and relative humidity. Wheat has different environmental requirements for each stage of development, especially with regard to water requirements and air temperature. In the tillering stage, the newly emerged plants have one or more sheaths. Subsequently, at the stem elongation stage, plant growth occurs, which reinforces the plant structure. At this stage, the ears are not yet visible, and the inflorescence is still wrapped in the flag leaf sheath until the booting stage. After this period, the crop enters the heading stage. At the beginning, the first ears are visible, and at the end, all ears are present outside the sheaths. The flowering stage occurs primarily in the main stem, then the tillers, starting in the apical part of the spike. At the end of flowering, the grains are in an aqueous phase. During the flowering stage, plants are extremely sensitive to low air temperatures. At the end of the cycle, at the stage of physiological maturity, grains start the reserve accumulation process. Early in the process, the grain content is milky, and later, the ripening of the grain indicates it is ready for harvesting. Conditions of high air temperatures, low water availability, and low soil moisture, combined with long sunny days, reduce the period of wheat maturation (Mundstock, 1999; Large, 1954). Water represents 80 to $95 \%$ of the mass of cells involved in maintenance, growth, and turgor of the plant, hydrolysis reactions, and photosynthesis. In addition to performing the function of a solvent, enabling the gases, minerals, and other solutes to enter the cell, water is also responsible for controlling the internal temperature of the plant. A reduction in water availability in plants leads to the reduction of cell solutes thus increasing the solute concentration. This causes the plasma membrane to become thicker, affecting the turgidity processes of cells, reducing the leaf area and causing stomatal closure. This results in a reduced rate of photosynthesis, influencing the plant development (Dias, 2008; Lacerda et al., 2007). In wheat, decreased water availability causes reduced growth by decreasing water potential, stomatal conductance, photosynthesis, and nitrogen assimilation. Wheat evapotranspiration in the southern region of Brazil is 312 $\mathrm{mm}$, with a maximum water consumption of $3.9 \mathrm{~mm} \mathrm{day}^{-1}$. The values of sensitivity coefficient to water deficit for each wheat crop development stage (kyi), referring to the vegetative, reproductive, and physiological ripening stage, are $0.2,0.6$, and 0.0 , respectively. The higher the value of kyi, the greater the losses in crop yield under drought conditions. The most sensitive developmental stage to be affected by lack of water is the flag leaf stage, followed by the flowering stage. During the milk-grain stage, wheat is the least sensitive to water stress (Cunha et al., 2009; Moreira and Cardoso, 2009; Roberts et al., 1998; Doorenbos and Kassam, 1994). Low water supply for long periods can reduce the number of days in the crop growth cycle. The cycle is measured by the number of days from emergence, to heading and physiological ripening. A lack of rainfall can reduce the plant growth period up to heading, or the grain filling period (Osório, 1992; Pedro Júnior et al., 2004). Excessive rainfall can lead to a reduction in quality, 


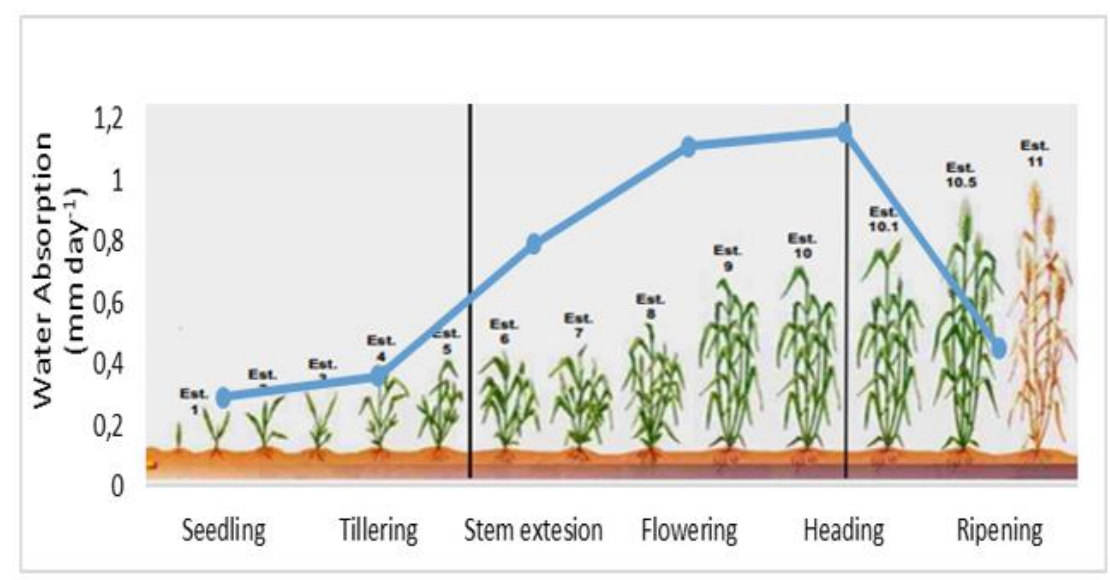

Fig 1. Water Consumption (mm day-1) for the phases of establishment, tillering, booting, flowering, grain formation and maturation. Adapted from Large, (1954), and average consumption of water in each development phase (Libardi and Costa, 1997).

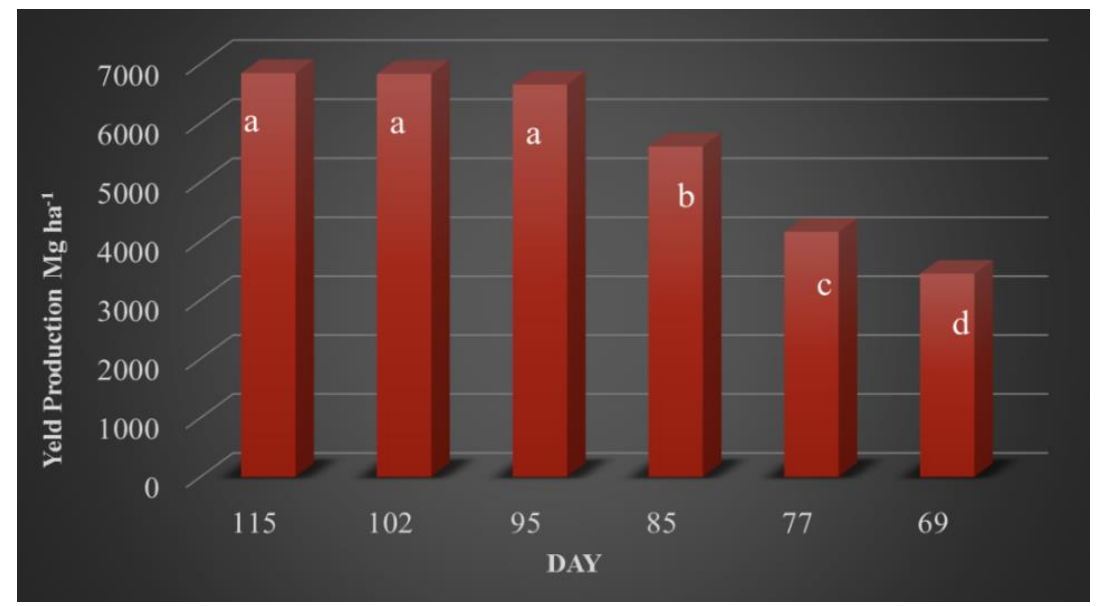

Fig 2. Wheat productivity affected by cutting water supply to $69,77.85,95,102$ and 115 days after planting. Adapted from Guerra and Antonini, (1996).

germination of grains still in the ear, and losses in grain yield (Guarienti et al., 2005).

\section{Wheat production affected by drought}

The water availability can cause significant changes in grain components, and consequently in grain quality; the changes differ in the event of excess water or lack of water. Plants that go through periods of drought suffer decreased photosynthetic activity during this period, consequently affecting the grain formation (Jiang et al., 2009). To obtain a quality grain, it is necessary that proteins accumulate in the grain. This process is strongly influenced by water availability, and the nutritional conditions in which the plant grows (Rodrigues and Teixeira, 2010). According to Libardi and Costa (1997), the average consumption of water by wheat was $347.2 \mathrm{~mm}$ over a 115-day cycle, or an average daily intake of approximately $3.02 \mathrm{~mm}$. The consumption was $0.70,0.93,2.21,3.74,5.48$ and $2.12 \mathrm{~mm} \mathrm{day}^{-1}$, for the phases of establishment, tillering, booting, flowering, grain formation, and grain maturation, respectively (Fig 1).

Doorenbos and Kassan (1979) stated that, if there is an adequate water supply during the establishment phase of the culture, the critical periods for water stress are: when the plants are nearing completion of the tillering phase and beginning stem elongation, during the head development till the beginning of the flowering period, and during the initial formation of productivity.

Singh (1981) investigated the sensitivity of the growth periods of wheat with respect to moisture, demonstrating that according to the concept of the "critical stage", the three periods of wheat development, in order of decreasing sensitivity, are the booting to heading stage, flowering and grain development, and vegetative stage.

Water stress in the stem elongation phase prevents some tillers from producing spikes, although it does not represent a complete loss of income, because before senescence, all assimilated are transported to the fertile tillers. The stress throughout the tillering stage has a negative effect on the production of tillers, dry weight of shoots, and number of ears per plant, but not on the plant height (Teruel and Smiderle, 1999).

Moreira and Cardoso (2009) observed that the suspension of irrigation in the milk stage of kernel development does not have much effect on the plant, and the stages of early head and ear emergence are more sensitive to water stress treatments. The productivity was more sensitive to stress during the emergence of the head, whereas vegetative growth 
tends to be the most affected by the suspension of irrigation in the early heading.

Guerra and Antonini (1996) studied the effect of cutting the supply of water to wheat (cultivar BR-12 Arowana) at 69,77, $85,95,102$, and 115 days after planting. These days correspond to the following developmental stages respectively: start of anthesis, watery caryopses, milky state, soft dough state, stiff dough state, and hard caryopsis., The effects studied were the grain yield, and grain quality (Fig. 2). They found a significant reduction in grain yield in the instances where irrigation was suspended before the grains in a state of hardness. This reduction in income was caused by a reduction in grain weight (per 1000 grains) and the weight per hectoliter of grain. The suspension of irrigation when the grain had reached the hard phase afforded savings of $99 \mathrm{~mm}$ of water, relative to when the irrigation treatment phase lasted until the caryopsis. The hard grain kernel state may be defined as one in which most of the grains can withstand nail pressure without breaking.

Herz and Rudorff (2001) studied water stress in four periods of growth (tillering, booting, grain filling, and physiological maturity), and observed that the grain production was reduced by water stress in the tillering stage $(22.7 \%)$ booting stage $(41.6 \%)$ and grain filling stage $(9.1 \%)$. Thus, the effects of low water availability are variable, and depend on the phenological stage of the plant and the duration and intensity of the water stress.

\section{Wheat resistance to drought}

The resistance of plants to drought is very complex, and its expression depends on the action and interaction of different morphological (reduced leaf area, leaf roll, wax content, efficient root system, and yield stability), physiological (reduction in transpiration, high efficiency in water use, stomatal closure, and osmotic adjustment), and biochemical (proline accumulation, polyamines, diamine, increased nitrate reductase activity, and increased carbohydrate storage) characteristics. However, knowledge about the genetic mechanisms that influence these traits is still limited (Mitra, 2001; Fumis and Pedras, 2002). The synthesis of proteins under stress conditions is inhibited and their degradation is accelerated, which results in the accumulation of free amino acids and amines (Larcher, 2000). The hallmark of a disorder in protein metabolism is the change in the proportion of amino acids, and a high concentration of proline (Larcher, 2000).

Usually, when plants are exposed to various types of environmental stress, notably water, they may accumulate proline, putrescine, and polyamines (Fumis and Pedras, 2002). The accumulation of these compounds in water deficit has been associated with the tolerance of plants to this unfavorable condition, and may represent a regulatory mechanism of water loss through increased cellular osmolarity (water potential) (Rodrigues et al., 1998; Fumis and Pedras, 2002; Marin et al., 2006). Additionally, the accumulation of proline as a compatible osmolyte, during and between periods of stress, is well documented (Shevyakova, 1984; Hare and Cress, 1997; Carceller et al., 1999; LazcanoFerrat and Lovatt, 1999; Mitra, 2001; Kishor et al., 2005).

The identification of genotypes that are tolerant to environmental stresses through classical breeding methods is difficult, because it is a characteristic with low heritability and is usually a genotype $\times$ environment interaction. This is in addition to the selection process usually occurring in differing conditions (Smith et al., 1990; Kirigwi et al., 2004). Thus, plant transformation has been demonstrated as an option for the development of wheat genotypes that are tolerant to drought, and are therefore more productive (Sahrawat et al., 2003).

Techniques for the genetic transformation of plants have been used in identifying genes responsible for their resistance to drought, as well as the transfer of these plant genotypes (Grover et al., 2001). Studies have shown that the manipulation of genes responsible for the biosynthesis of low-molecular-weight metabolites has resulted in plants with an increased tolerance to drought and salinity (Molinari, 2003).

\section{Conclusion}

The effects of drought on the wheat plant are variable, depending on the phenological stage of the plant, as well as the duration, intensity, and frequency of the drought. The crop evapotranspiration increases the duration of the phenological cycle until the stages comprising the beginning of heading until the end of flowering, which is the most drought-sensitive stage of the crop. At ripening, the evapotranspiration decreases to save and allocate the energy to grain yield. In the initial phase, drought can affect the number and density of plants most severely.How the water deficit affects the development of cultures depends on when it occurs. In the initial emergence phase, the drought can severely affect the number of plants per square meter. In the tillering phase, the number of tillers per plant is affected, during stem elongation, plant height is affected. At the flowering stage, processes related to fertilization and the fixation of grain is affected most severely, resulting in a decrease in the number of viable seeds per area. In the grain formation stage, the capacity to translocate the assimilates to the grain is affected, which in turn affects the grain weight

\section{Acknowledgement}

To CAPES (Coordination for the Improvement of Higher Education Personnel), for financial support and providing a scholarship to the first author.

\section{References}

Abitrigo (2015) Associação Brasileira da Indústria do trigo. Available in: 〈http://www.abitrigo.com.br/derivados.asp > Accessed on November 2, 2015.

Bajaj S, Targolli J, Liu L, Ho TD, Wuet R (1999) Transgenic approaches to increase dehydration-stress tolerance in plants. Mol Breed. 5:493-503.

Boschini APM (2010) Produtividade e qualidade de grãos de trigo influenciados por nitrogênio e lâminas de água no Distrito Federal, 2010. 55 f. Dissertation (Master in Agronomy).

Bray EA (1993) Molecular responses to water deficit. Plant Physiol. 103: 1035-1040.

Carceller MM, Prystupa P, Lemcoff JH (1999) Remobilization of proline and other nitrogen compounds from senescing leaves of maize under water stress. J Agron Crop Sci. 183:61-66.

Cunha GR, Pires JLF, Dalmago GA, Caierão E, Pasinato A (2009) Trigo. In: Monteiro JEBA (Org). Agrometeorologia dos cultivos: o fator meteorológico na produção agrícola. Brasília, $530 \mathrm{p}$.

DaMatta FM (2007) Ecophysiology of tropical tree crops: an introduction. Water relations of plants. 19: 239-244.

Dias LB (2008) Água nas plantas. Monograph, Universidade Federal de Lavras, Lavras-MG, 53 p. 
Doorembos J, Kassam, AH (1979) Yield response to water. Roma, FAO, 193 p.

Doorenbos J; Kassam Am (1994). Efeito da água no rendimento das culturas. Campina Grande: FAO, (Estudos FAO, Irrigação e Drenagem 33).

Embrapa Trigo. Available in: <http://www.cnpt.embrapa.br/culturas/trigo/index.htm>. Accessed on: November 3, 2015.

Fumis TF; Pedras JF (2002) Proline, diamine and polyamines accumulation in wheat cultivars submitted to water deficits. Pesq agropec bras. 37: 449-453.

Grant RF (1992) Interaction between carbon dioxide and water deficits affecting canopy photosynthesis: simulation an testing. Crop Sci. 32:1322-1328.

Grover A, Kapoor A, Satya Lakshmi O, Agarwal S, Sahi C, Katiyar-Agarwal S, Agarwal M, Dubey H (2001) Understanding molecular alphabets of the plant abiotic stress responses. Curr Sci. 80: 206-216.

Guarienti EM, Ciacco CF, Cunha GR, Del Duca LJA, Camargo CMO (2005) Efeitos da precipitação pluvial, da umidade relativa do ar e de excesso e déficit hídrico do solo no peso do hectolitro, no peso de mil grãos e no rendimento de grãos de trigo. Ciênc Tecnol Aliment. 25: 412-418.

Guerra AF, Antonini JCA (1996) Época de suspender as irrigações da cultura do trigo. Pesq agropec bras. 31: 823828.

Gutkoski LC, Durigon A, Mazzutti S, Silva ACT, Elias MC (2008) Efeito do período de maturação de grãos nas propriedades físicas e reológicas de trigo. Ciênc Tecnol Aliment. 28: 888-894.

Hare PD; Cress WA (1997) Metabolic implications of stressinduced proline accumulation in plants. Plant Growth Regul. 21: 79-102.

Ingram J, Bartels D (1996) The molecular basis of dehydration tolerance in plants. Annu Rev Plant Physiol. 47: 377-403.

Jiang D, Yue H, Wollenweber B, Tan W, Mu H, Bo Y, Dai T, Jing Q, Cao W (2009) Effects of post-anthesis grought glutenin subunits and glutenin macropolymers content in wheat grain. J Agron Crop Sci. 195: 89-97.

Kirigwi F, van Ginkel M, Trethowan R, Sears RG, Rajaram S, Paulsen GM (2004) Evaluation of selection strategies for wheat adaptation across water regimes. Euphytica 135: 361-371.

Kramer PJ (1983) Water relations of plants. New York: Academic Press p.146-186.

Lacerda CF, Filho JE, Pinheiro CB (2007) Fisiologia Vegetal. Fortaleza: UFC, 2007, 356 p.

Larcher W. (2000) Ecofisiologia vegetal. São Carlos: RiMa $531 \mathrm{p}$.

Large EC (1954) Growth stages in cereals. Illustration of the Feeks scale. Plant Pathol. 3: 128-129.

Lazcano-Ferrat I, Lovatt CJ (1999) Relationship between relative water content, nitrogen pools, and growth of Phaseolus vulgaris L. and P. acutifolius A. Gray during water deficit. Crop Sci. 39: 467-475.

Libardi VCM, Costa MB (1997) Consumo de água da cultura do trigo (Tricutum aestivum, L.). Rev FZVA. 4: 17-22.

Marin A, Santos DMM, Banzatto DA, Codognotto LM (2006) Influence of water availability and soil acidity on the level of free proline in pigeon pea. Pesq agropec bras. 41:355-358

Mitra J (2001) Genetics and genetic improvement of drought resistance in crop plants. Curr Sci. 80: 758-763.

Molinari HBC (2003) Transformação genética de portaenxertos para Citrus spp. visando obter maior tolerância ao estresse hídrico. Londrina: Universidade Estadual de
Londrina, 120p. Dissertation (Masters in Genetics and Molecular Biology).

Moreira DR, Cardoso VJM (2009) Estresse hídrico e produtividade em Triticum aestivum cv. Anahuac e Triticum Durum cv. IAC 1003. Naturalia, 32:23-34.

Moreira JCS, Sousa CNA (1999) Resultados da $26^{\circ}$ elite durum wheat yield trial. Passo Fundo: Embrapa Trigo, (Comunicado técnico on line n.6)

Mundstock CM (1999) Planejamento e Manejo integrado da lavoura de trigo. Porto Alegre: Evangraf, $227 \mathrm{p}$.

Osório EA (1992) A cultura do trigo. São Paulo: Globo, 218 p.

Oviedo AFP, Herz R, Rudorff BFT (2001) Efeito do Estresse Hídrico e da Densidade de Plantio no Uso da Radiação e Produtividade da Cultura do Trigo (Triticum aestivum L.). Rev biociênc Taubaté. 7(1): 23-33.

Pedro Júnior MJ (2004) Temperatura-base, graus-dia e duração do ciclo para cultivares de triticale. Bragantia, 63: 447-453.

Rodrigues O, Lhamby JCB, Didonet AD, Marchese JA, Scipioni C (1998) Efeito da deficiência hídrica na produção de trigo. Pesq Agropec Bras. 33: 839-846.

Rodrigues O, Teixeira MCC (2003) Efeito da adubação nitrogenada, arranjo de plantas e redutor de crescimento no acamamento e em características de cevada. Passo Fundo: Embrapa Trigo.

Rodrigues O, Teixeira MCC (2010) Bases ecofisiológicas para manutenção da qualidade do trigo. Embrapa Trigo. Passo Fundo - RS, 84p.

Santos RF, Carlesso R (1998) Water deficit and morphologic and physiologic behavior of the plants. Rev Bras Eng Agric Ambient. 2: 287-294.

Sarto, MVM, Lana MC, Rampim L, Rosset JS, Molin PVD (2012) Desenvolvimento Inicial do Milho e Atributos Químicos do Solo em Função de Diferentes Doses de Silicato de Cálcio. Scientia Agraria Paranaensis. 11: 22-31.

Sarto MVM, Rampim L, Lana MC, Rosset JS, Ecco M, Wobeto JR. (2014) Atributos químicos do solo e desenvolvimento da cultura do trigo em função da adubação silicatada. Agrarian. 7: 390-400.

Sarto MVM, Lana MC, Rampim L, Rosset JS, Wobeto JR, Ecco M, Bassegio D, Costa PF (2014) Effect of silicate on nutrition and yield of wheat. Afr J Agric Res. 9: 956-962.

Sarto MVM, Lana MC, Rampim L, Rosset JS, Wobeto JR (2015) Effects of silicate application on soil fertility and wheat yield. Semina. 36: 4071-4082.

Sarto, MVM, do Carmo Lana M, Rampim L, Rosset JS, Inagaki AM and Bassegio D (2016) Effects of silicon (Si) fertilization on gas exchange and production in Brachiaria. Aust J Crop Sci. 10: 307-313.

Sahrawat AK, Becker D, Lütticke S, Lörz H (2003) Genetic improvement of wheat via alien gene transfer, an assessment. Plant Sci. 165: 1147-1168.

Shevyakova NI (1984). Metabolism and the physiological role of proline in plants under conditions of water and salt stress. Sov Plant Physiol. 30: 597-608.

Shinozaki K, Yamaguchi-Shinozaki K (2000) Molecular responses to dehydration and low temperature: differences and cross talk between two stress signaling pathways. Curr Opin Plant Biol. 3:217-223.

Singh SD (1981) Moisture-sensitive growth stages of dwarf wheat and optimal sequencing of evapotranspiration deficits. Agron J. 73: 387-391.

Slatyer RO (1969) Physiological significance of internal water relations to crop yield. In: Eastin FA et al. (eds.). Physiological aspects of crop yield. Madison: WI. Inst., p.53-83. 
Sleper DA, Poehlman JM (2006) Breeding field crops. Ames: Blackwell Pub Iowa, $424 \mathrm{p}$.

Smith OS, Smith JSC, Bowen SL, Tenborg RA, Wall, SJ (1990) Similarities among a group of elite maize inbreeds as measured by pedigree, F1 grain yield, heterosis, and RFLPs. Theor Appl Genet. 80:833-840.

Taiz L, Zeiger E (2013) Fisiologia vegetal. Porto Alegre: Artmed, 343-368.

Taiz L, Zeiger E (2004) Fisiologia vegetal. Porto Alegre: Artmed, 449-48.

Tibola CS, Fernandes JMC, Lorini I, Scheeren PL, Miranda MZ de, (2008) Produção integrada de trigo - safra 2007. Passo Fundo: Embrapa Trigo, 10p.
Teruel DA, Smiderle OJ (1999) Trigo. In: Castro PRC \& Kluge RA Ecofisiologia de cultivos anuais. São Paulo: Nobel, 13-40p.

Usda - United States Department Of Agriculture (2015) Foreign Agricultural Service. Production, Supply and Distribution Online: Custom Query. USDA.

Vesohoski F, Marchioro VS, Franco FA, Cantelle A (2011) Componentes do rendimento de grãos em trigo e seus efeitos diretos e indiretos na produtividade. Rev Ceres. 58: 337-341. 